\title{
ANALISIS FAKTOR-FAKTOR YANG MEMPENGARUHI KESEJAHTERAAN NELAYAN DI KABUPATEN JEMBRANA
}

\author{
Ni Made Dwi Kusumayanti ${ }^{1}$ \\ I Nyoman Djinar Setiawina ${ }^{2}$ \\ I Made Suyana Utama ${ }^{3}$ \\ Fakultas Ekonomi dan Bisnis Universitas Udayana ${ }^{1}$ \\ Abang220775@gmail.com/081298761333 \\ Fakultas Ekonomi dan Bisnis Universitas Udayana² \\ Fakultas Ekonomi dan Bisnis Universitas Udayana ${ }^{3}$
}

\begin{abstract}
This study aims to analyze the influence of social capital on income, analyze the factors of production to income, analyze the influence of social capital to the welfare of fishermen, analyze the influence of production factors to fisherman's welfare in Jembrana regency, and analyze the influence of social capital and production factors through income mediator to fisherman's welfare in Jembrana District. In this research use survey method by taking sample 98 responden from population of 4,876 people, with technique of descriptive statistical data analysis and analysis of SEM PLS. The results of testing in the study showed: 1) Social capital positively affects the income of fishermen; Factor of Production have positive effect to fisherman's income; 2) Social capital has a positive effect on fishermen's welfare in Jembrana Regency; Factor of Production have positive effect to fisherman's prosperity in Jembrana Regency; 3) Revenues mediate the influence of social capital and production factors on fishermen's welfare in Jembrana District.
\end{abstract}

Keywords: Welfare, Income, Social Capital, Factor of Production, and Fisherman.

\begin{abstract}
Abstrak: Analisis Faktor-Faktor Yang Mempengaruhi Kesejahteraan Nelayan di Kabupaten Jembrana. Penelitian ini bertujuan untuk menganalisis pengaruh modal sosial terhadap pendapatan, menganalisis faktor produksi terhadap pendapatan, menganalisis pengaruh modal sosial terhadap kesejahteraan nelayan, menganalisis pengaruh faktor produksi terhadap kesejahteraan nelayan di Kabupaten Jembrana, dan menganalisis pengaruh modal sosial dan faktor produksi melalui mediator pendapatan terhadap kesejahteraan nelayan di Kabupaten Jembrana. Dalam penelitian ini menggunakan metode survey dengan mengambil sampel 98 responden dari populasi sejumlah 4.876 orang, dengan teknik analisis data statistik deskriptif dan analisis Jalur SEM PLS. Hasil pengujian dalam penelitian menunjukan: 1) Modal sosial berpengaruh positif terhadap pendapatan nelayan; Faktor Produksi berpengaruh positif terhadap pendapatan nelayan; 2) Modal sosial berpengaruh positif terhadap kesejahteraan nelayan di Kabupaten Jembrana; Faktor Produksi berpengaruh positif terhadap kesejahteraan nelayan di Kabupaten Jembrana; 3) Pendapatan memediasi pengaruh modal sosial dan faktor produksi terhadap kesejahteraan nelayan di Kabupaten Jembrana.
\end{abstract}

Kata Kunci: Kesejahteraan, Pendapatan, Modal sosial, Faktor Produksi, dan Nelayan. 


\section{PENDAHULUAN}

Perikanan merupakan sumber daya alam yang memiliki peranan penting dan sangat strategis bagi pembangunan nasional. Pemanfaatan modal sosial di masyarakat nelayan merupakan alternatif yang sangat krusial dalam rangka menutupi kecenderungan menurunnya sumberdaya alam dan dalam pemberdayaan ekonomi masyarakat nelayan. Peningkatan kualitas Faktor-faktor produksi merupakan salah satu alternatif untuk meningkatkan hasil tangkap masyarakat nelayan yang sebagian besar berdomisili di daerah pesisir. Pendapatan nelayan sangat tergantung dari hasil tangkapannya.

Dalam rangka memperbaiki taraf hidup nelayan dan meningkatkan produksi perikanan dipengaruhi oleh faktor modal kerja, teknologi yang digunakan, jam kerja, dan sebagainya (Dahuri, 2009). Pemanfaatan sumber daya ikan dan hayati yang ada di perairan Indonesia dapat memberikan kontribusi signifikan terhadap kesejahteraan masyarakat pesisir khususnya nelayan. Masyarakat nelayan merupakan masyarakat yang dianggap sebagai masyarakat golongan miskin dibandingkan dengan masyarakat lainnya. Kehadiran perikanan skala kecil yang masih menggunakan teknologi sederhana atau tradisional memberikan kesempatan kerja bagi masyarakat pesisir dan juga memberi pendapatan yang cukup tinggi kepada daerah (Puspitasari, 2015).

Riefsa (2014) menyatakan bahwa pemanfaatan sumberdaya ikan dan kelautan berperan penting dalam upaya peningkatan kesejahteraan masyarakat pesisir khususnya nelayan. Manfaat yang diperoleh antara lain adanya penyediaan bahan kebutuhan dasar, peningkatan penghasilan, kesempatan kerja, perolehan devisa, dan pembangunan daerah.

Salah satu tolak ukur keberhasilan pembangunan nasional adalah Produk Domestik Regional Bruto (PDRB). Sektor pertanian merupakan penyumbang terbesar terhadap Produk Domestik Regional Bruto Kabupaten Jembrana dan Sub Sektor perikanan memiliki kontribusi tertinggi dibandingkan sub sektor lainnya pada sektor pertanian, dapat dilihat dari Tabel 1.1.

Sub kategori perikanan merupakan penyumbang terbesar terhadap pembentukan nilai tambah lapangan usaha PDRB Kabupaten Jembrana selama periode 2012-2016, ratarata kontribusi perikanan mencapai 35,41 persen. Pada tahun 2016 sub sektor perikanan memberikan kontribusi kepada PDRB sebesar 34,52 persen atau Rp 539.2164.185,00. Laju pertumbuhan dari sub kategori perikanan sangat fluktuatif. Pertumbuhan tertinggi

Tabel 1.1

Peranan Sub Lapangan Usaha terhadap NTB Lapangan Usaha Pertanian, Kehutanan, dan Perikanan Kabupaten Jembrana, 2012-2016 (Persen)

\begin{tabular}{lccccc}
\hline \multicolumn{1}{c}{ Lapangan Usaha } & 2012 & 2013 & 2014 & 2015 & 2016 \\
\hline $\begin{array}{l}\text { Pertanian, Kehutanan, } \\
\text { dan Perikanan }\end{array}$ & 100,00 & 100,00 & 100,00 & 100,00 & 100,00 \\
$\begin{array}{l}\text { 1. Tanaman Pangan, } \\
\text { Holtikultura, dan } \\
\text { lainnya }\end{array}$ & 19,88 & 19,39 & 18,80 & 20,40 & 19,40 \\
2. Perkebunan & 24,36 & 23,59 & 22,56 & 22,95 & 24,29 \\
$\begin{array}{l}\text { 3. Peternakan } \\
\text { 4. Jasa Pertanian dan }\end{array}$ & $0,8,65$ & 20,76 & 20,88 & 20,57 & 20,82 \\
$\begin{array}{l}\text { Perburuan } \\
\text { 5. Kehutanan dan }\end{array}$ & 0,89 & 0,88 & 0,87 & 0,93 \\
penebangan kayu & 0,04 & 0,04 & 0,04 & 0,04 & 0,04 \\
6. Perikanan & 35,20 & 35,33 & 36,84 & 35,17 & 34,52 \\
\hline r Data Primer (Kuesioner)2019 & & & & &
\end{tabular}


Tabel 1.2

Jumlah Nelayan Provinsi Bali menurut Kabupaten/Kota

Tahun 2016

\begin{tabular}{llc}
\hline No & Kabupaten/ Kota & Jumlah Nelayan (orang) \\
\hline 1 & Denpasar & 820 \\
2 & Badung & 1.959 \\
3 & Tabanan & 1.169 \\
4 & Jembrana & $\mathbf{4 . 8 7 6}$ \\
5 & Buleleng & 4.159 \\
6 & Karangasem & 4.646 \\
7 & Klungkung & 1.164 \\
8 & Gianyar & 634 \\
9 & Bangli & 523 \\
& Jumlah & $\mathbf{1 9 . 9 5 0}$ \\
\hline Sumber: Dinas Perikanan dan Kelautan Pemerintah Provinsi Bali, 2016
\end{tabular}

Tabel 1.3

Produksi Perikanan Tangkap (Laut dan PU) Provinsi Bali Menurut Kabupaten/Kota Tahun 2012 - 2015 (Ton)

\begin{tabular}{llrrrr}
\hline \multirow{2}{*}{ No } & Kab/ Kota & \multicolumn{4}{c}{ Tahun } \\
\cline { 3 - 6 } & & \multicolumn{1}{c}{2012} & \multicolumn{1}{c}{2013} & \multicolumn{1}{c}{2014} & \multicolumn{1}{c}{2015} \\
\hline 1 & Denpasar & $30,573.5$ & $45,083.4$ & $45,718.5$ & $34,104.90$ \\
2 & Badung & $4,632.4$ & $4,761.1$ & $6,113.1$ & $6,474.10$ \\
3 & Tabanan & 815.3 & 826.9 & 884.0 & 828.20 \\
$\mathbf{4}$ & Jembrana & $\mathbf{1 0 , 4 8 2 . 0}$ & $\mathbf{1 4 , 1 0 3 . 6}$ & $\mathbf{2 2 , 4 3 6 . 1}$ & $\mathbf{2 0 , 3 7 9 . 2 3}$ \\
5 & Buleleng & $13,374.5$ & $14,342.1$ & $17,809.2$ & $16,307.90$ \\
6 & Karangasem & $18,083.5$ & $20,597.8$ & $21,534.5$ & $24,910.34$ \\
7 & Klungkung & $2,065.9$ & $2,100.4$ & $2,000.9$ & $1,889.60$ \\
8 & Gianyar & 864.1 & 866.0 & 814.9 & 505.53 \\
9 & Bangli & 843.5 & 910.5 & 929.9 & 851.90 \\
& Jumlah & $\mathbf{8 1 , 7 3 4 . 7}$ & $\mathbf{1 0 3 , 5 9 1 . 9}$ & $\mathbf{1 1 8 , 2 4 1 . 1}$ & $\mathbf{1 0 6 , 2 5 1 . 7}$ \\
\hline
\end{tabular}

terjadi pada tahun 2014 yaitu sebesar 9,94 persen tetapi terus melambat menjadi $-1,16$ persen pada tahun 2016. Kondisi tersebut tidak bisa dilepaskan dari ketergantungan sub sektor perikanan terutama perikanan tangkap terhadap kondisi cuaca laut. Melambatnya pertumbuhan sub kategori perikanan sangat berdampak terhadap pertumbuhan lapangan usaha pertanian secara keseluruhan. (Badan Pusat Statistik Kabupaten Jembrana, 2017).

Kabupaten Jembrana memiliki jumlah nelayan terbesar dibandingkan Kabupaten/ Kota lain di Provinsi Bali. Data jumlah nelayan pada Tabel 1.2.

Sektor perikanan di Kabupaten Jembrana merupakan sektor andalan untuk dijadikan sumber mata pencaharian bagi rakyat. Penduduk yang menetap di sepanjang pantai di Kabupaten Jembrana mengandalkan mata pencaharian sebagai Nelayan. Seluruh kecamatan di Kabupaten Jembrana merupakan wilayah pesisir dimana seluruhnya mempunyai pantai. Potensi perikanan laut Kabupaten Jembrana didukung oleh sumberdaya ikan di perairan Selat Bali dan perairan Samudera Hindia. Proses untuk mengasilkan sejumlah 
Tabel 1.4

Nilai Produksi Perikanan Tangkap (Laut dan PU) Provinsi Bali

Menurut Kabupaten/Kota Tahun 2012-2015 (dalam juta rupiah)

\begin{tabular}{llrrrr}
\hline \multirow{2}{*}{ Ko } & Kab/ Kota & \multicolumn{4}{c}{ Tahun } \\
\cline { 3 - 6 } & & \multicolumn{1}{c}{2012} & \multicolumn{1}{c}{2013} & \multicolumn{1}{c}{2014} & \multicolumn{1}{c}{2015} \\
\hline 1 & Denpasar & $638,112,700.0$ & $984,110,450.0$ & $1,179,258,650.0$ & $789,370,528.10$ \\
2 & Badung & $65,748,200.0$ & $68,313,030.0$ & $115,487,727.5$ & $105,194,979.30$ \\
3 & Tabanan & $23,946,700.0$ & $23,962,550.0$ & $28,287,400.0$ & $19,081,787.00$ \\
$\mathbf{4}$ & Jembrana & $\mathbf{6 8 , 7 5 4 , 3 0 0 . 0}$ & $\mathbf{8 2 , 5 6 1 , 3 9 8 . 6}$ & $\mathbf{1 3 1 , 7 7 4 , 1 1 6 . 9}$ & $\mathbf{1 1 1 , 9 5 7 , 6 9 6 . 7 0}$ \\
5 & Buleleng & $242,904,200.0$ & $280,908,000.0$ & $394,135,500.0$ & $313,459,823.60$ \\
6 & Karangasem & $197,962,225.0$ & $245,365,800.0$ & $297,708,470.0$ & $290,105,682.70$ \\
7 & Klungkung & $21,609,400.0$ & $17,661,400.0$ & $20,636,600.0$ & $21,741,275.40$ \\
8 & Gianyar & $21,847,900.0$ & $26,473,300.0$ & $25,793,300.0$ & $13,056,022.90$ \\
9 & Bangli & $15,022,800.0$ & $17,019,800.0$ & $18,939,100.0$ & $17,978,179.60$ \\
& Jumlah & $\mathbf{1 , 2 9 5 , 9 0 8 , 4 2 5 . 0}$ & $\mathbf{1 , 7 4 6 , 3 7 5 , 7 2 8 . 6}$ & $\mathbf{2 , 2 1 2 , 0 2 0 , 8 6 4 . 4}$ & $\mathbf{1 , 6 8 1 , 9 4 5 , 9 7 5 . 3}$ \\
\hline
\end{tabular}

Sumber: Dinas Perikanan dan Kelautan Pemerintah Provinsi Bali,2016

ikan dan manfaat ekonomi, harus dilakukan melalui proses produksi. Faktor produksi harus ada untuk menghasilkan suatu produksi yang lebih baik. (Fauzi, 2010). Produksi perikanan tangkap Provinsi Bali menurut Kabupaten/ Kota Tahun 2012 - 2015 disajikan pada Tabel 1.3 .

Rata-rata produksi perikanan yang dihasilkan di Kabupaten Jembrana dari tahun 2012-2015 menempati posisi ketiga setelah Kota Denpasar dan karangasem, hal ini tidak sebanding dengan jumlah nelayan yang menempati posisi teratas. Nilai produksi perikanan tangkap di Kabupaten Jembrana menempati posisi keempat setelah Denpasar, Buleleng, dan Karangasem. Diambil dari data Tahun 2015, rata-rata nilai produksi per nelayan per tahun menempati peringkat ketiga terendah setelah Kabupaten Tabanan dan Bangli. Data nilai produksi perikanan tangkap Provinsi Bali menurut Kabupaten/Kota Tahun 2012-2015 pada Tabel 1.4.

Menurunnya produksi ikan di Kabupaten Jembrana disebabkan karena berbagai faktor yang tidak mendukung di Selat Bali untuk melakukan kegiatan penangkapan ikan. Nelayan di PPN Pengambengan mengaku memiilih libur melaut karena cuaca buruk, jika dipaksakan hasilnya rugi dan tangkapan ikan sedikit. Selama menganggur dari kegiatan melaut, para nelayan memperbaiki jukung, alat tangkap, hingga menjadi buruh serabutan. (Dinas Kelautan Perikanan dan Kehutanan Kab. Jembrana, 2016).

Produksi perikanan tangkap di Kabupaten Jembrana pada tahun 2016, sebesar $10.422,03$ ton, menurun sebesar $47,89 \%$ atau 9.557 ton dibandingkan dengan tahun 2015. Data jumlah produksi ikan menurut sub sektor perikanan di Kabupaten Jembrana Tahun 2016 pada Tabel 1.5.

Nilai produksi perikanan tangkap tahun 2016 sebesar Rp. 84.241.782,60 mengalami penurunan sebesar $27 \%$ atau $\mathrm{Rp}$. 31.161.272,45 dibandingkan dengan tahun 2015. Nilai Produksi Ikan Menurut Sub Sektor Perikanan Per Kecamatan di Kabupaten Jembrana Tahun 2016 pada Tabel 1.6.

Produksi perikanan tangkap di Kabupaten Jembrana tahun 2016 didominasi oleh ikan lemuru, yaitu sebesar 68,60\% atau 7.149,72 ton, dengan nilai produksi sebesar Rp 32.466.414.100,-. Selain ikan lemuru sebagai sumber daya ikan utama, jenis sumberdaya ikan pelagis lain-lainnya yaitu ikan layang, layur, tongkol, manyung, kembung, bawal, dan ikan lainnya (Dinas Kelautan, Perikanan dan Kehutanan Kabupaten Jembrana, 2016). Produksi perikanan tangkap per jenis ikan di Kabupaten Jembrana Tahun 
Tabel 1.5

Jumlah Produksi Ikan Menurut Sub Sektor Perikananan di Kabupaten Jembrana Tahun 2016

\begin{tabular}{llrrrr}
\hline No. & Kecamatan & Perikanan Laut & Perikanan & Darat & \\
\hline & & $\begin{array}{c}\text { Penangkapan } \\
(\mathrm{kg})\end{array}$ & $\begin{array}{c}\text { Tambak } \\
(\mathrm{kg})\end{array}$ & $\begin{array}{c}\text { Air Tenang } \\
(\mathrm{kg})\end{array}$ & \multicolumn{1}{c}{$\begin{array}{c}\text { Jumlah } \\
(\mathrm{kg})\end{array}$} \\
\hline 1 & Melaya & 565,630 & 222,291 & 77,670 & 845,591 \\
2 & Negara & $8,178,806$ & 834,263 & 52,450 & $9,065,519$ \\
3 & Jembrana & 818,480 & $1,123,502$ & 39,480 & $1.981,462$ \\
4 & Mendoyo & 272,850 & 51,359 & 124,700 & 448,909 \\
5 & Pekutatan & 606,260 & 444,252 & 69,010 & $1,119,522$ \\
\hline & Tahun 2016 & $\mathbf{1 0 , 4 2 2 , 0 2 6}$ & $\mathbf{2 , 6 7 5 , 6 6 7}$ & $\mathbf{3 6 3 , 3 1 0}$ & $\mathbf{1 3 , 4 6 1 , 0 0 8}$ \\
\hline & Tahun 2015 & $19,999,365$ & $1,371,620$ & 296,898 & $21,667,883$ \\
& Tahun 2014 & $21,655,401$ & $1,716,000$ & $1,329,600$ & $24,721,001$ \\
& Tahun 2013 & $14,101,800$ & 959,600 & 298,100 & $15,366,042$ \\
& Tahun 2012 & $10,479,100$ & $1,066,516$ & 315,553 & $11,874,969$ \\
& Tahun 2011 & $12,616,034$ & 721,140 & 510,949 & $13,863,335$ \\
& Tahun 2010 & $26,453,800$ & $1,414,700$ & 218,200 & $25,016,325$ \\
\hline
\end{tabular}

Sumber: Dinas Kelautan Perikanan dan Kehutanan Kab. Jembrana, 2016

Tabel 1.6

Nilai Produksi Perikananan

Kabupaten Jembrana Tahun 2010-2016

\begin{tabular}{clrrrr}
\hline No. & Kecamatan & Perikanan Laut & \multicolumn{1}{c}{ Perikanan } & \multicolumn{1}{c}{ Darat } & \\
\hline & & $\begin{array}{c}\text { Penangkapan } \\
(\mathrm{kg})\end{array}$ & $\begin{array}{c}\text { Tambak } \\
(\mathrm{kg})\end{array}$ & $\begin{array}{c}\text { Air Tenang } \\
(\mathrm{kg})\end{array}$ & \multicolumn{1}{c}{$\begin{array}{c}\text { Jumlah } \\
(\mathrm{kg})\end{array}$} \\
\hline 1 & Melaya & $8,885,234.10$ & $11,722,550,00$ & $1,813,770.00$ & $22,421,554.10$ \\
2 & Negara & $48,652,968.20$ & $43,861,700.00$ & $1,173,270.00$ & $93,687,938.20$ \\
3 & Jembrana & $60,695,000.00$ & $13,393,967.61$ & $871,950.00$ & $74,960,917.61$ \\
4 & Mendoyo & $4,313,353.39$ & $37,850,000.00$ & $2,908,570.00$ & $45,071,923.39$ \\
5 & Pekutatan & $8,996,259.30$ & $14,533,750.00$ & $1,629,050.00$ & $25,159,059.30$ \\
\hline & Thn 2016 & $\mathbf{8 4 , 2 4 1 , 7 8 2 . 6 0}$ & $\mathbf{1 6 8 , 6 6 3 , 0 0 0 . 0 0}$ & $\mathbf{8 . 3 9 6 . 6 1 0 , 0 0}$ & $\mathbf{2 6 1 , 3 0 1 , 3 9 2 . 6 0}$ \\
\hline & Thn 2015 & $115,403,055.05$ & $68,117,355.00$ & $6,132,766.00$ & $189,653,176.05$ \\
& Thn 2014 & $101,727,106.71$ & $107,742,500.00$ & $20,826,350.00$ & $230,595,956.71$ \\
& Thn 2013 & $82,649,998.00$ & $463,870.00$ & $3,683,450.00$ & $151,555,993.00$ \\
& Thn 2012 & $68,696,100.00$ & $716,674.00$ & $5,737,717.00$ & $114,041,997.00$ \\
& Thn 2011 & $25,232,068.00$ & $1,248,566.00$ & $6,283,582.00$ & $59,153,016.00$ \\
& Thn 2010 & $38,193,505.00$ & $5,711,107.90$ & $46,299,600.00$ & $93,449,550.90$ \\
\hline
\end{tabular}

Sumber: Dinas Kelautan Perikanan dan Kehutanan Kab. Jembrana, 2016

2016 pada Tabel 1.7.

Untuk menutupi kecenderungan menurunnya sumber daya alam tersebut, modal sosial merupakan sebuah alternatif dalam rangka meningkatkan kekuatan pelakupelaku ekonomi serta dapat meningkatkan efisiensi. Modal sosial seperti norma, jaringan, dan kepercayaan, dalam suatu komunitas dapat menjadikan anggota di dalamnya lebih berdaya (Gunawan, 2005).

Tingkat pendapatan sering digunakan para ahli ekonomi sebagai pengukuran tingkat 
Tabel 1.7

Produksi Perikanan Tangkap per Jenis Ikan di Kabupaten Jembrana Tahun 2016

\begin{tabular}{rlrrrr}
\hline No & \multicolumn{1}{c}{ Jenis Ikan } & \multicolumn{2}{c}{ Volume } & \multicolumn{2}{c}{ Nilai } \\
\hline & \multicolumn{1}{c}{ Ton } & \multicolumn{1}{c}{$\%$} & \multicolumn{1}{c}{ Rp 000 } & \multicolumn{1}{c}{$\%$} \\
\hline 1 & Teri & 192.55 & 1.8474 & $2,518,951.00$ & 2.9901 \\
2 & Kembung & 27.14 & 0.2604 & $482,590.00$ & 0.5729 \\
3 & Layang & 147.89 & 1.4189 & $2,114,265.50$ & 2.5098 \\
4 & Pelegis kecil lainnya & 160.80 & 1.5428 & $2,017,072.00$ & 2.3944 \\
5 & Tongkol abu-abu & 448.70 & 4.3051 & $7,157,242.00$ & 8.4961 \\
6 & Kenyar & 124.04 & 1.1901 & $1,811,602.00$ & 2.1505 \\
7 & Selengseng & 577.01 & 5.5362 & $7,093,498.00$ & 8.4204 \\
8 & Lemadang & 192.10 & 1.8431 & $2,887,495.00$ & 3.4276 \\
9 & Kakap Merah & 18.40 & 0.1765 & $247,604.00$ & 0.2939 \\
10 & Swangi/Mata besar & 94.40 & 0.9057 & $1,795,159.00$ & 2.1310 \\
11 & Layur & 619.19 & 5.9409 & $14,249,675.00$ & 16.9152 \\
12 & Sembilang & 39.50 & 0.3790 & $521,900.00$ & 0.6195 \\
13 & Ikan Demersal lainnya & 348.50 & 3.3437 & $5,151,145.00$ & 6.1147 \\
14 & Kerapu Karang & 21.20 & 0.2034 & $544,500.00$ & 0.6464 \\
15 & Baronang & 68.50 & 0.6572 & $1,469,226.00$ & 1.7441 \\
16 & Kuwe & 7.04 & 0.0675 & $71,600.00$ & 0.0850 \\
17 & Tembang & 22,28 & 0.2138 & $139,815.50$ & 0.1660 \\
18 & Bawal hitam & 0.39 & 0.0037 & $9,750.00$ & 0.0116 \\
19 & Peperak & 7.88 & 0.0756 & $54,879.00$ & 0.0651 \\
20 & Belanak & 0.08 & 0.0008 & $1,560.00$ & 0.0019 \\
21 & Lisong & 150.32 & 1.4423 & $1,378,580.50$ & 1.6365 \\
22 & Tongkol komo & 4.59 & 0.0440 & $50,534.00$ & 0.0600 \\
23 & Tenggiri & 0.26 & 0.0025 & $6,500.00$ & 0.0077 \\
24 & Alu-alu & 0.02 & 0.0002 & 225.00 & 0.0003 \\
25 & Lemuru & 7.149 .72 & 68.5989 & $32,466,414.10$ & 38.5396 \\
\hline \multicolumn{1}{c}{ Total } & $\mathbf{1 0 . 4 2 2 . 5 0}$ & $\mathbf{1 0 0 . 0 0}$ & $\mathbf{8 4 . 2 4 1 , 7 8 2 . 6 0}$ & $\mathbf{1 0 0 . 0 0}$ \\
\hline
\end{tabular}

Sumber: Dinas Kelautan Perikanan dan Kehutanan Kab. Jembrana, 2016

kesejahteraan. Kesejahteraan yang tercipta bukan saja kesejahteraan secara ekonomis dan material tetapi juga mencakup kesejahteraan lahir dan batin serta kesejahteraan materiil dan sepirituil. Kesejahteraan tidak hanya dinilai dari besar kecilnya pendapatan tapi lebih daripada itu, seseorang dikatakan sejahtera jika mampu terpenuhi kebutuhan secara lahir dan batin (BPS, 2015).

Berdasarkan latar belakang uraian diatas maka rumusan masalah didalam penelitian ini adalah:
1) Apakah modal sosial dan faktor produksi berpengaruh terhadap pendapatan nelayan di Kabupaten Jembrana?

2) Apakah modal sosial dan faktor produksi berpengaruh terhadap kesejahteraan nelayan di Kabupaten Jembrana?

3) Apakah pendapatan memediasi pengaruh modal sosial dan faktor produksi terhadap kesejahteraan nelayan di Kabupaten Jembrana?

Bertolak dari pokok permasalahan tersebut diatas, maka penelitian ini mempunyai tujuan: 
1) Untuk menganalisis pengaruh modal sosial dan faktor produksi terhadap pendapatan nelayan di Kabupaten Jembrana;

2) Untuk menganalisis pengaruh modal sosial dan faktor produksi terhadap kesejahteraan nelayan di Kabupaten Jembrana; dan

3) Untuk menganalisis pengaruh modal sosial dan faktor produksi melalui mediator pendapatan terhadap kesejahteraan nelayan di Kabupaten Jembrana.

Manfaat praktis dari penelitian ini diharapkan dapat dipergunakan sebagai masukan pemikiran kepada Pemerintah Kabupaten Jembrana terkait kesejahteraan nelayan di Kabupaten Jembrana. Disamping itu juga diharapkan juga dapat beruguna bagi nelayan sebagai bahan informasi yang berhubungan dengan modal sosial, faktor produksi, pendapatan dan kesejahteraan nelayan di Kabupaten Jembrana, dan manfaat teoritisnya diharapkan bisa menjadikan penelitian ini sebagai wahana untuk mengaplikasikan dan menginterpretasikan pengetahuan yang diperoleh dari bangku kuliah, khususnya yang memiliki keterkaitan dengan permasalahan dan kesejahteraan nelayan di Kabupaten Jembrana.

Kesejahteraan secara umum mempunyai makna untuk memajukan kesejahteraan bagi masyarakat secara menyeluruh bukan hanya kesejahteraan per individu. Kesejahteraan tidak hanya dinilai dari besar kecilnya pendapatan, namun lebih daripada itu, seseorang sejahtera jika mampu memenuhi kebutuhan secara lahir dan batin (BPS, 2015). Para ahli ekonomi umumnya melakukan pengukuran tingkat kesejahteraan dengan melihat variasi ekonomi, yaitu tingkat pendapatan (Supartono, dkk, 2011). Pendapatan atau keuntungan yang diperoleh diharapkan dapat memenuhi kebutuhan hidup seorang pekerja (Winardi, 1996). Tingkat pendapatan mencerminkan pertumbuhan ekonomi yang harus dicapai dalam suatu perekonomian yang baik, yaitu perekonomian yang mampu memberikan kesejahteraan bagi seluruh penduduk di negara atau daerah (Todaro, 2004).
Penggunaan faktor-faktor produksi secara efisien akan menghasilkan kenaikan produksi yang optimal, seperti: 1) Modal kerja. Biaya yang dibutuhkan nelayan dalam proses penangkapan ikan cukup besar untuk operasi selama melaut. Modal merupakan barang atau uang yang bersama-sama faktor produksi lainnya yang dalam pengelolaannya menghasilkan barang baru (Hermanto, 1993).

2) Lama Waktu Melaut (Jam kerja). Lama waktu melaut bagi nelayan berkisar 10-15 jam, hal tersebut disebabkan beberapa hal yaitu, rusaknya ekosistem laut diperaian Indonesia dan juga disebabkan oleh overfhising atau penangkapan yang berlebihan, sehingga nelayan sering mengalami jumlah tangkapan yang tidak maksimal (Jamal, 2014).

3) Teknologi. Rendahnya tingkat pendidikan menyebabkan kemampuan masyarakat nelayan menyerap informasi, teknologi dan adopsi relatif terbatas (Silviyanti, 2015). Teknologi dalam bidang perikanan yang meningkat, mampu menghemat waktu, meningkatkan laba/ peningkatan pendapatan (Akangbe, 2015). Berdasarkan besarnya mesin (motor) perahu yang digunakan, diukur dengan GT (Gross Tonage). Menurut Setianto (2007), Perahu motor dibagi menjadi: 1) Perahu kecil yaitu $<5$ GT - 10 GT, dengan panjang kurang dari 9 meter. 2) Perahu sedang yaitu 10 GT 30 GT, dengan panjang 9-11 meter. 3) Perahu besar yaitu lebih dari $30 \mathrm{GT}$, dengan panjang 11 meter atau lebih. Teknologi, kekayaan alam, modal fisik,modal keuangan dan sumberdaya manusia merupakan faktor penting dalam menentukan kapasitas masyarakat untuk menghasilkan suatu produk dalam ekonomi (Akangbe, 2015).

Namun demikian, faktor-faktor produksi tersebut belum mampu melihat tingkat interdependensi antar individu dalam masyarakat kalau tidak didukung oleh faktor institusi dan nilai yang berlaku di masyarakat. Determinan kesejahteraan (well-being) hanya terbatas pada faktor fisik (alam, ekonomi, dan sumberdaya manusia), dan sedikit sekali melihat kesejahteraan dalam konteks modal sosial, padahal modal sosial merupakan sumberdaya terpenting dalam kehidupan 
masyarakat karena modal ini merupakan jaringan atau hubungan keluarga terhadap dunia luar baik bersifat formal maupun informal untuk memecahkan berbagai persoalan yang ada di masyarakat termasuk masalah peningkatan kesejahteraan keluarga (Sakata, 2004).

Konsep modal sosial dapat dipakai untuk memahami berfungsinya pasar, dimana adanya modal sosial menurunkan biaya transaksi. Karena adanya kepercayaan dalam bertransaksi akan menghilangkan atau meminimkan kontrak-kontrak resmi (Fukuyama, 2000 dan Coleman,2000). Fukuyama (2000) mendefinisikan modal sosial sebagai norma yang dapat mendorong kerjasama antaranggota masyarakat. Putnam (2000) modal sosial sebagai berikut :

"... physical capital refers to physical objects and humancapital refers to the properties of individuals, sosial capital refers toconnections among individuals sosial networks and the norms ofreciprocity and trustworthiness that arise from them... ....." "......A society of many virtuous but isolated individuals isot necessarily rich in sosial capital"

Modal sosial menekankan kerja sama antar individu dalam suatu kelompok dengan jaringan sosial, norma, nilai, dan kepercayaan antar sesama yang lahir dari anggota kelompok untuk memahami berbagai masalah sosial (Fukuyama, 2000).

Berdasarkan permasalahan dan teoriteori yang telah diuraikan, maka hipotesis penelitian dirumuskan:

1) Modal sosial dan faktor produksi berpengaruh positif terhadap pendapatan nelayan di Kabupaten Jembrana;

2) Modal sosial dan faktor produksi berpengaruh positif terhadap kesejahteraan nelayan di Kabupaten Jembrana;

3) Pendapatan memediasi pengaruh modal sosial dan faktor produksi terhadap kesejahteraan nelayan di Kabupaten Jembrana.

\section{METODE PENELITIAN}

Kabupaten Jembrana memiliki jumlah nelayan terbanyak di antara Kabupaten lain di Provinsi Bali, sedangkan produksinya masih berada dibawah kabupaten lain dan menurunnya tingkat produksi pada tahun 2016 dibadingkan tahun sebelumnya, menjadikan Kabupaten Jembrana layak dijadikan lokasi penelitian. Ruang Lingkup Penelitian adalah variabel modal sosial direfleksikan oleh kepercayaan, jaringan, dan norma, variabel faktor produksi yang direfleksikan oleh lama waktu melaut, modal kerja, dan teknologi, serta variabel pendapatan dan variabel kesejahteraan nelayan di Kabupaten Jembrana. Penelitian ini dilakukan pada tahun 2017. Variabel penelitian yang digunakan adalah:

1) Variabel terikat adalah kesejahteraan nelayan di Kabupaten Jembrana;

2) Variabel bebas variabel bebasnya adalah modal sosial dan faktor produksi;

3) Variabel antara yaitu pendapatan nelayan adalah sebagai variabel yang memediasi pengaruh faktor modal sosial dan faktor produksi terhadap kesejahteraan nelayan di Kabupaten Jembrana.

Populasi penelitian adalah nelayan yang berada di wilayah Kabupaten Jembrana yang berjumlah 4.876 orang. Penentuan sampel menggunakan metode random purposive sampling, dengan jumlah responden sebanyak 98 orang. Dalam Pengumpulan data digunakan beberapa teknik pengumpulan data yaitu observasi, dokumentasi, dan wawancara Mendalam. Teknik analisis data yang digunakan adalah statistik deskriptif dan analisis PLS.

\section{HASIL PENELITIAN DAN PEMBAHASAN \\ Model persamaan dalam penelitian ini sesuai dengan Gambar 1.1.}

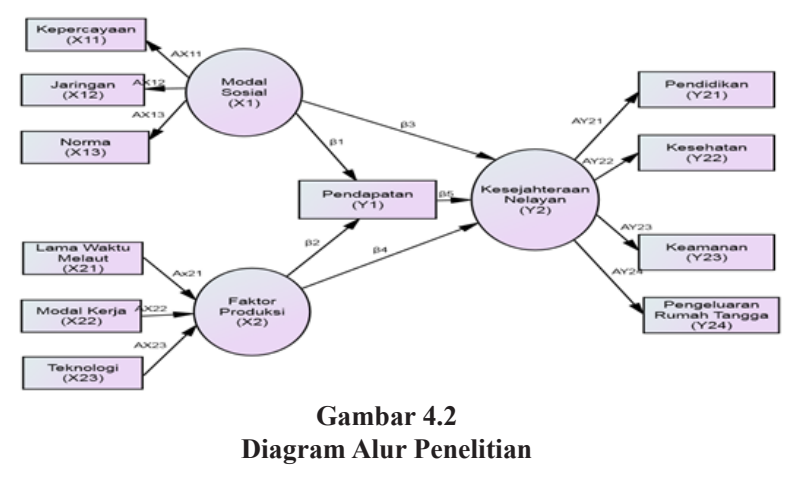


Tabel 1.8

Outer Loading Indikator Terhadap Konstruk Modal Sosial, Faktor Produksi, Pendapatan, dan Kesejahteraan nelayan di Kabupaten Jembrana, Th. 2017

\begin{tabular}{lccc}
\hline Hubungan Antar Variabel & Loading & $\begin{array}{c}\text { Standard } \\
\text { Error }\end{array}$ & T-Statistics \\
\hline X11 < - Modal Sosial & 0,907 & 0,025 & 36,191 \\
X12 < - Modal Sosial & 0,932 & 0,019 & 50,054 \\
X13 < - Modal Sosial & 0,882 & 0,030 & 29,645 \\
\hline X21 - > Faktor Produksi & 0,574 & 0,103 & 5,583 \\
X22 - > Faktor Produksi & 0,509 & 0,092 & 5,513 \\
X23 - > Faktor Produksi & 0,978 & 0,020 & 49,366 \\
\hline Y21 < Kesejahteraan & 0,870 & 0,044 & 19,596 \\
Y22 < - Kesejahteraan & 0,924 & 0,037 & 24,887 \\
Y23 < - Kesejahteraan & 0,890 & 0,041 & 21,498 \\
Y24 < - Kesejahteraan & 0,661 & 0,072 & 9,191 \\
\hline Sumber: Hasil Penelitian, 2017 & & &
\end{tabular}

Hasil analisis statistik pengaruh modal sosial dan faktor produksi terhadap pendapatan dan kesejahteraan nelayan di Kabupaten Jembrana secara kesulurahan dapat tersaji pada Gambar 1.2.

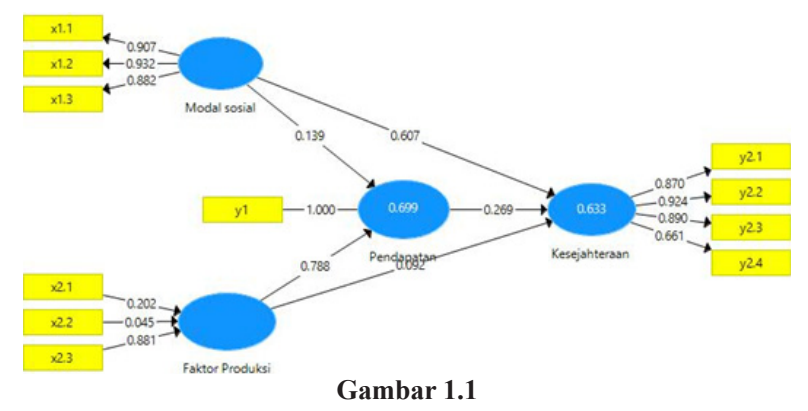

Full Model Kesejahteraan Nelayan di Kabupaten Jembrana

Hasil pengujian menunjukan nilai $\mathrm{R}^{2}$ pendapatan $(\mathrm{Y} 1)=0,699, \mathrm{R}^{2}$ kesejahteraan nelayan $(\mathrm{Y} 2)=0,633$, maka model dikatakan baik. Variabel Modal Sosial (X1) nilai loading tertinggi di miliki oleh variabel jaringan (X12) 0,932, variabel faktor produksi (X2) dimiliki oleh variabel teknologi (X23) 0,978, dan variabel kesejahteraan (Y2) nilai loading tertinggi di miliki oleh variabel kesehatan (Y22) $0,924$.

\section{Uji Validitas Outer Model}

Beberapa analisis dilakukan untuk mengetahui indikator pembentuk konstruk diantaranya;

1). Convergent Validity, disajikan pada Tabel 1.8 .

Keseluruhan indikator pembentuk konstruk Modal Sosial (X1), Faktor Produksi (X2), Pendapatan (Y1), dan Kesejahteraan (Y2) adalah signifikan dengan nilai t hitung lebih besar dari t tabel $(1,64)$, nilai loading di atas 0,5 yang berarti bahwa konstruk yang di buat telah memenuhi syarat Convergent Validity.

\section{2) Discriminant Validity}

Hasil crossloading indikator terhadap konstruk Modal Sosial (X1), Faktor Produksi (X2), Pendapatan (Y1), dan Kesejahteraan (Y2) Nelayan di Kabupaten Jembrana tersaji pada Tabel 1.9.

Tabel 1.9 menunjukan Discriminant Validity telah terpenuhi karena crossloading lebih tinggi pada konstruknya dibandingkan dengan konstruk lainnya. Contoh, crossloading minimal 0,882 dimiliki oleh konstruk modal 
Tabel 1.9

Cross Loading Indikator Terhadap Konstruk Modal Sosial, Faktor Produksi, Pendapatan, dan Kesejahteraan nelayan di Kabupaten Jembrana, Tahun 2017

\begin{tabular}{lccccc}
\hline Konstruk & Indikator & $\begin{array}{c}\text { Faktor } \\
\text { Produksi }\end{array}$ & Kesejahteraan & $\begin{array}{c}\text { Modal } \\
\text { Sosial }\end{array}$ & Pendapatan \\
\hline Modal Sosial & X11 & 0,177 & 0,662 & 0,907 & 0,303 \\
& X12 & 0,223 & 0,643 & 0,932 & 0,297 \\
& X13 & 0,324 & 0,667 & 0,882 & 0,348 \\
\hline Faktor Produksi & X21 & 0,574 & 0,331 & 0,355 & 0,440 \\
& X22 & 0,509 & 0,292 & 0,227 & 0,391 \\
& X23 & 0,978 & 0,449 & 0,210 & 0,816 \\
\hline Kesejahteraan & Y21 & 0,251 & 0,870 & 0,670 & 0,267 \\
& Y22 & 0,301 & 0,924 & 0,674 & 0,359 \\
& Y23 & 0,230 & 0,890 & 0,665 & 0,289 \\
& Y24 & 0,348 & 0,661 & 0,425 & 0,509 \\
\hline Sumber: Hasil Penelitian, 2017 & & & & &
\end{tabular}

Tabel 1.10

Average Variance Extracted (AVE), Composite Reliability, dan Cronbachs Alpha Konstruk Modal Sosial, Faktor Produksi, Pendapatan, dan Kesejahteraan Nelayan di Kabupaten Tabanan, Thn. 2017

\begin{tabular}{lccc}
\hline Variabel Konstruk & AVE & $\begin{array}{c}\text { Composite } \\
\text { Reliability }\end{array}$ & Cronbach's Alpha \\
\hline Modal Sosial (X1) & 0,823 & 0,933 & 0,892 \\
\hline Faktor Produksi (X2) & - & - & - \\
\hline Kesejahteraan (Y2) & 0,710 & 0,906 & 0,857 \\
\hline Sumber: Hasil Penelitian, 2017 & & &
\end{tabular}

sosial (X1) sedangkan indikator konstruk lain memiliki crossloading paling besar 0,667.

Kelayakan konstruk yang dibuat bisa di lihat dari Discriminant Validity (DV) melalui Average Variance Extracted (AVE), composite reliability $(\mathrm{pc})$ umunya digunakan untuk indikator reflektif untuk mengukur konsistensi internal konstruk, dan Cronbach's Alpha. Hasil olahan data tersaji pada Tabel 1.10 .

Tabel 1.10 menunjukan bahwa konstruk Modal Sosial (X1), Pendapatan (Y1), dan Kesejahteraan Nelayan (Y2) di Kabupaten Jembrana sangat baik, sebab memiliki nilai dv lebih dari 0,50 untuk Average Variance Extracted (AVE), dan di atas 0,70 untuk Composite reliability. Nilai Cronbach's Alpha lebih dari 0,60, kecuali variabel Faktor Produksi (X2) yang merupakan indikator formatif.

\section{Uji Inner Model}

Uji Inner Model dilakukan dengan melihat pengaruh signifikan antar konstruk yang diuji, seperti yang tersaji pada Tabel 1.11

Tabel 1.8 menunjukan nilai loading hubungan antar variabel masing-masing lebih dari 0,1. Variabel X1 secara signifikan 
Tabel 1.11

Inner Loading Antar Variabel Konstruk Modal Sosial, Faktor Produksi, Pendapatan, dan Kesejahteraan nelayan di Kabupaten Jembrana, Thn. 2017

\begin{tabular}{lcccc}
\hline $\begin{array}{c}\text { Hubungan } \\
\text { Antar Variabel }\end{array}$ & Loading & $\begin{array}{c}\text { Standard } \\
\text { Error }\end{array}$ & T-Statistics & P-Values \\
\hline X1 - > Y1 & 0,139 & 0,056 & 2,501 & 0,013 \\
X1 - > Y2 & 0,644 & 0,099 & 6,530 & 0,000 \\
X2 - > Y1 & 0,788 & 0,035 & 22,303 & 0,000 \\
X2 - > Y2 & 0,303 & 0,085 & 3,548 & 0,000 \\
Y1 - > Y2 & 0,269 & 0,101 & 2,668 & 0,008 \\
\hline Sumber: Hasil Penelitian, 2017 & & &
\end{tabular}

Tabel 1.12

Koefisien Jalur Antar Variabel

\begin{tabular}{lc}
\hline Hubungan Antar Variabel & $\mathrm{X} 2$ \\
\hline $\mathrm{X} 1$ - > Y1 - > Y2 & 55,884 \\
$\mathrm{X} 2$ - > Y1 - > Y2 & 61,760 \\
\hline
\end{tabular}

Sumber: Hasil Penelitian, 2017

berpengaruh terhadap Y1 dan Y2, variabel X2 berpengaruh signifikan terhadap Y1 dan Y2, variabel Y1 berpengaruh signifikan terhadap Y2, artinya semua konstruk berhubungan positif dan signifikan terhadap kesejahteraan nelayan karena nilai t-hitung $<$ t-tabel 1,66.

3. Pengaruh tidak langsung modal sosial dan faktor produksi terhadap kesejahteraan melalui pendapatan.

Variabel mediasi pendapatan (Y1) yang dipengaruhi oleh modal sosial (X1) dan faktor produksi (X2) terhadap kesejahteraan nelayan (Y2) di analisis dengan metode Sobel yang dimodifikasi oleh McKinon tersaji pada tabel 1.12

Hasil perkalian koefisien jalur yang dibagi dengan standar error dari jalur yang dilalui oleh variabel modal sosial (X1), pendapatan (Y1), dan kesejahteraan nelayan (Y2) sebesar 55,884, variabel faktor produksi (X2), pendapatan (Y1), dan kesejahteraan nelayan (Y2) memiliki nilai 61,760. Nilai masing-masing lebih besar dari 3,81 pada tingkat signifikansi alpha $10 \%$, berarti variabel pendapatan (Y1) signifikan memidiasi variabel modal sosial (X1) dan faktor produksi (X2) terhadap kesejahteraan nelayan (Y2).

\section{Pengaruh total modal sosial, faktor produksi, dan pendapatan terhadap} kesejahteraan nelayan.

Penilaian Goodness of fit pada model PLS dilihat dari nilai predictive prevelance $\left(\mathrm{Q}^{2}\right)$ untuk mengukur nilai observasi yang dihasilkan oleh model serta estimasi parameternya. Perhitungan melalui predictive prevelance yaitu:

$$
\begin{aligned}
& \mathrm{Q}^{2}=1-\left(1-\mathrm{R} 1^{2}\right)\left(1-\mathrm{R} 2^{2}\right) \\
& \mathrm{Q}^{2}=1-(1-0,699)(1-0,633) \\
& \mathrm{Q}^{2}=0,889
\end{aligned}
$$

Perhitungan diatas menunjukkan $\mathrm{Q}^{2}$ $=0,889$ lebih besar dari nol yang tergolong cukup besar karena mendekati 1. Dapat disimpulkan bahwa secara keseluruhan model adalah fit, artinya telah mencerminkan situasi dan kondisi secara nyata yang terjadi di lapangan. 
Modal sosial, faktor produksi, dan pendapatan memiliki pengaruh positif dan signifikan terhadap kesejahteraan nelayan. Modal sosial memiliki pengaruh yang paling besar terhadap kesejahteraan, disebabkan diantaranya karena adanya ketaatan terhadap norma yang berlaku dalam masyarakat nelayan sepeti ketaatan untuk tidak mengotori wilayah pantai secara nyata mampu meningkatkan derajat kesehatan nelayan yang kebanyakan tinggal di wilayah pesisir. Sesuai dengan pendapat Lenggono (2004), bahwa norma mengandung sanksi sosial yang dapat mencegah individu berbuat yng menyimpng dari kebiasaan yang berlaku dalam masyarakat. Eratnya hubungan kekerabatan atau jaringan sosial, dan tingginya tingkat kepercayaan nelayan terhadap sesama nelayan maupun kepada pengepul juga mampu meningkatkan kesejahteraan nelayan itu sendiri. Adanya komunikasi yang baik dapat meningkatkan kesadaran masyarakat akan pentingnya pendidikan keluarga dalam upaya peningkatan kualitas hidup. Sesuai dengan pendapat Lin, dkk. (2001) bahwa dengan jaringan sosial antara pelaku-pelaku individual, grup, dan organisasi dapat berguna sebagai sumber daya untuk menghasilkan pengembalian yang bersifat positif. Sejalan dengan hasil penelitian Gunarsa (2016) bahwa jaringan yang baik dapat mempermudah penyebaran informasi diantara para nelayan.

Dengan meningkatnya kualitas modal sosial nelayan di Kabupaten Jembrana maka kesejahteraan para nelayan cenderung meningkat. Hal ini sejalan dengan pendapat Fukuyama (2000) bahwa ada hubungan erat antara modal sosial dan kesejahteraan. Negara atau bangsa yang tingkat kesejahteraannya tinggi adalah bangsa yang memiliki modal sosial tinggi.Dalam Semakin baik hubungan yang dimiliki antar dengan komunitas nelayan maka semakin dapat meningkatkan kesejahteraan nelayan setempat. Sejalan juga dengan penelitian Gunarsa (2016) bahwa meskipun kegiatan penangkapan ikan bisa menimbulkan potensi perselisihan, namun tingkat kepercayaan, ketaatan norma, dan adanya jaringan sosial antar nelayan yang cukup kental merupakan modal tersendiri bagi kelangsungan usaha dan mampu meningkatkan kesejahteraan rumah tangga.

Dalam variabel faktor produksi (X2), indikator teknologi berpengaruh paling dominan terhadap kesejahteraan nelayan. Teknologi alat tangkap yang menjadi acuan pada penelitian ini memiliki lima variasi yaitu bubu, pukat cincin, jala, pancing, dan GillNet (jaring insang). Semakin canggih alat tangkap yang di gunakan maka semakin banyak pula hasil tangkapan yang diperoleh. Nelayan yang menggunakan bubu hanya bisa menangkap ikan di pinggir pantai dengan hasil yang sedikit. Nelayan yang menggunakan pancing mampu menangkap ikan lebih banyak. Alat tangkap jala mampu menjaring ikan lebih banyak dan lebih mudah dibandingkan menggunakan pancing sehingga dapat meningkatkan penghasilan. Pilihan alat tangkap yang lebih modern adalah pukat cincin dan gillnet (jaring insang).

Nelayan yang ada di kawasan Mendoyo dan Pekutatan dominan menggunakan alat tangkap gillnet dengan hasil tangkapan yang lebih banyak yaitu berkisar 20 sampai dengan $50 \mathrm{~kg}$ per sekali melaut. Hal ini tentu berpengaruh terhadap pendapatan nelayan, karena pendapatan nelayan tergantung pada hasil tangkapannya.Meningkatnya pendapatan nelayan berpengaruh terhadap kesejahteraan para nelayan. Hal ini sejalan dengan pendapat dari Sastrawidjaya (2002) bahwa semakin canggih teknologi maupun alat tangkap yang digunakan nelayan maka akan semakin meningkatkan produktifitas, sehingga lebih meningkatkan produksi, dan masyarakat akan memperolah penghasilan yang lebih tinggi.

Lama waktu melaut atau jam kerja nelayan yang ada di Kabupaten Jembrana bervariasi dari 5 sampai 15 jam dalam sehari, 20 sampai dengan 30 kali melaut dalam sebulan, sehingga jam kerja nelayan mencapai 140 sampai dengan 400 jam dalam sebulan. Dalam sehari dominan jam kerja nelayan di Kabupaten Jembrana adalah 8 sampai dengan 10 jam. Semakin lama waktu yang digunakan untuk melakukan pekerjaan semakin besar kemungkinan mendapatkan hasil tangkap yang 
lebih banyak dengan alat tangkap yang sama. Hal ini sejalan dengan penelitian Masyuri (1999) yang menyatakan bahwa waktu yang dilakukan lebih lama dan jarak tempuh lebih jauh dalam pekerjaan melaut, mempunyai kemungkinan memperolah hasil tangkapan (produksi) yang lebih besar dibandingkan dengan penangkapan ikan dekat pantai.

Modal kerja yang digunakan oleh nelayan di Kabupaten Jembrana cukup besar dan bervariasi bisa mencapai 50 persen dari pendapatan bersih yang di dapat nelayan yang menggunakan alat tangkap yang lebih canggih, dengan modal yang sama mampu memperoleh hasil tangkap yang lebih besar sehingga pendapatan nelayan juga lebih besar. Hal ini mengindikasikan bahwa teknologi yang paling besar berpengaruh terhadap tingkat pendapatan dan kesejahteraan di Kabupaten Jembrana. Hal ini senada dengan penelitian Lumban (2015) bahwa biaya dalam kegiatan nelayan bervariasi, yaitu biaya dan biaya tidak. Biaya tetap adalah biaya yang relatif tetap jumlahnya dan terus dikeluarkan walaupun hasil tangkapan ikan (produksi) di peroleh banyak atau sedikit.

Kesejahteraan nelayan di Kabupaten Jembrana di pengaruhi modal sosial dan faktor produksi melalui pendapatan, artinya untuk dapat mempercepat derajat kesejahteraan nelayan dapat dilakukan dengan peningkatan variabel modal sosial (jaringan, kepercayaan, norma) dan faktor ekonomi (lama waktu melaut, modal kerja, dan teknologi), dan pendapatan. Sejalan dengan pendapat Sukirno (2014) bahwa pendapatan didukung oleh kemampuan faktor-faktor produksi dan faktor pendukung lainnya dalam menghasilkan barang dan jasa. Semakin besar kemampuan faktor-faktor pendukung, semakin besar pula pendapatan yang dihasilkan dan kesejahteraan relatif meningkat.

Dengan meningkatnya pendapatan maka nelayan mampu untuk meningkatkan kualitas pendidikan keluarganya ke jenjang pendidikan yang lebih tinggi, menjaga kondisi kesehatan dengan pengobatan yang lebih baik. Sejalan dengan penelitian Rosni (2012) bahwa Kesejahteraan masyarakat dapat dilihat dengan kemampuan masyarakat untuk mengakses pendidikan yang merupakan layanan pemerintah. tetapi hasil penelitian ini bertentangan dengan penelitian Lujianti (2016) bahwa bahwa nelayan di Kampung Nelayan Seberang seluruhnya memliki tingkat kesejahteraan yang yang tergolong rendah ditunjukkan dengan tingkat pendapatan yang masih rendah, kesehatan yang rendah, dan pendidikan yang rendah.

Dengan pendapatan yang semakin meningkat pengeluaran rumah tangga nelayan di Kabupaten Jembrana cenderung meningkat pula. Senada dengan penelitian Carrera (2017) yang menyatakan bahwa ketika pendapatan dari nelayan Desa Ketapang bertambah maka konsumsi mereka juga bertambah, tetapi bertambahnya tidak terlalu besar, penambahan tidak terjadi pada pengeluaran pangan, tetapi pada pengeluaran kebutuhan akan pendidikan, rekreasi, barang mewah serta saving akan bertambah besar. Sejalan juga dengan pendapat Soediyono (1995) bahwa pendapatan naik maka konsumi akan naik. Dengan terpenuhinya kebutuhan hidup para nelayan mencerminkan kesejahteraan nelayan itu sendiri. Soekartawi (2003), menjelaskan pendapatan merupakan selisih antara biaya yang dikeluarkan selama melakukan kegiatan usaha dengan penerimaan yang diperoleh dari hasil tangkap. Pendapatan nelayan di Kabupaten Jembrana rata-rata di atas Upah Minimum Kabupaten (UMK) di Kabupaten Jembrana sebesar Rp 2.006.617,00. Tingkat pendapatan nelayan yang semakin tinggi akan meningkatkan juga daya belinya terhadap jenis barang atau jasa yang dibutuhkan. Terbukti dengan semakin tinggi pendapatan nelayan di Kabupaten Jembrana, pengeluaran rumah tangga atau konsumsi rumah tangga mereka semakin besar. Dimana pernyataan ini sejalan dengan penelitian Rosni (2012) bahwa pendapatan yang diterima mampu mempengaruhi pola hidup dan hubungan social ditengah masyarakat, karena besar kecilnya pendapatan berpengaruh terhadap daya beli untuk memenuhi kebutuhan hidup. Semakin tinggi pendapatan maka kemampuannya dalam membeli barang-barang menjadi lebih 
baik untuk mencukupi pemenuhan kebutuhan sosial ekonomi keluarganya.

Tempat kerja yang berbahaya dapat menimbulkan rasa cemas sehingga menjadikan pekerja merasa tidak aman dalam menjalankan kegiatannya. Tingkat keamanan merupakan salah satu indikator dari kesejahteraan. Nelayan di Kabupaten Jembrana lebih mengutamakan keselamatan diri jika cuaca tidak mendukung untuk melakukan kegiatan. Dari hasil penelitian, nelayan lebih memilih libur melaut saat cuaca buruk sehingga mereka merasa aman dalam bekerja. Hal ini sejalan dengan pendapat Purbayanto (2004), jika kebutuhan akan keamanan, keselamatan dan kemakmuran ini dapat terpenuhi, maka akan terciptalah kesejahteraan. Sejalan pula dengan penelitian Gunarsa (2016) yang menyatakan meskipun bergelut dengan gelombang laut yang tinggi tetapi nelayan di Kabupaten Tabanan masih tetap merasa aman dan nyaman menggeluti profesinya karena sudah ada alat keselamatan yang disedikan di perahu para nelayan.

Variasi dari perubahan modal sosial (kepercayaan, jaringan, norma), faktor produksi (lama waktu melaut, modal kerja, teknologi), dan pendapatan berpengaruh terhadap variasi perubahan kesejahteraan nelayan di Kabupaten Jembrana tetapi dipengaruhi juga oleh faktor lain yang tidak dimasukan dalam model penelitian ini.

\section{SIMPULAN DAN SARAN}

Kesimpulan yang dapat ditarik dari hasil pembahasan adalah:

1) Modal sosial (X1) berpengaruh positif terhadap pendapatan nelayan (Y1), yang artinya dengan meningkatkan kualitas modal sosial maka tingkat pendapatan nelayan cenderung meningkat. Faktor produksi (X2) berpengaruh positif terhadap pendapatan nelayan (Y1) di Kabupaten Jembrana yang artinya dengan meningkatkan kualitas faktor ekonomi maka pendapatan cenderung meningkat.

2) Modal sosial (X1) berpengaruh positif terhadap kesejahteraan nelayan (Y2) di Kabupaten Jembrana yang artinya dengan meningkatnya kualitas modal sosial maka tingkat kesejahteraan juga cenderung meningkat. Faktor produksi (X2) berpengaruh positif terhadap kesejahteraan nelayan (Y2) di Kabupaten Jembrana artinya bahwa dengan meningkatkan kualitas faktor ekonomi maka tingkat kesejahteraan nelayan cenderung meningkat.

3) Pendapatan (Y1) berpengaruh positif terhadap kesejahteraan nelayan (Y2) di Kabupaten Jembrana artinya bahwa dengan meningkatkan pendapatan maka tingkat kesejahteraan cenderung meningkat.

Adapun saran yang dapat penulis berikan adalah:

1) Sebaiknya nelayan membentuk koperasi nelayan agar lebih mudah mendapatkan pinjaman modal.

2) Untuk meningkatkan pendapatan nelayan yang tergolong rendah, sebaiknya nelayan menggunakan alat tangkap yang lebih canggih agar perolehan hasil tangkap lebih banyak.

3) Kebersihan pantai dan lingkungan tempat tinggal agar tetap dijaga untuk kepentingan bersama.

4) Pemerintah lebih intens melakukan pendampingan dan sosialisasi kepada nelayan agar informasi mengenai teknologi penangkapan ikan bisa terserap dengan baik.

\section{DAFTAR RUJUKAN}

Agnes, Puspitasari Sudarmo, at.al 2015. Social Economics Characteristics Of Coastal Small-Scale Fisheries In Tegal City, Indonesia. International Journal of Scientific \& Technology Research Volume 4, Issue 01.

Akangbe, J.A, at.all. 2015. Effects of improved fish production technology on the output of fish farmers in Ilorin, Kwara State, Nigeria. Ruhuna Journal of Science Vol 6: 50-62, Nigeria: Department of Agricultural Extension and Rural Development, University of Ilorin.

BPS Kabupaten Jembrana. 2016. Produk 
Domestik Bruto Kabupaten Jembrana Atas Dasar harga berlaku Menurut lapangan Usaha (jutaan rupiah).

BPS Provinsi Bali. 2015. Garis Kemiskinan, Jumlah dan Persentase Penduduk Miskin, P1, dan P2 per Kabupaten/ Kota di provinsi Bali tahun 2015.

Case, Karl E dan Ray C Fair. 2007. PrinsipPrinsip Ekonomi (edisi kedelapan). Terjemahan oleh Y. Andri Zaimur. Jakarta: Erlangga.

Carrera, Viola. 2017. Hubungan Antara Pendapatan dengan Pola Konsumsi Masyarakat Nelayan di Desa Ketapang Kecamatan Padang Cermin Kabupaten Pesawaran. Bandar Lampung: Universitas Malang.

Dahuri. R. 2009. Pengembangan Rencana Pengelolaan Pemanfaatan Berganda Ekosistem Mangrove di Sumatra. Bogor: Fakultas Perikanan IPB dan Ketua Program Pengelolaan Wilayah Pesisir dan Lautan PPLH Lembaga Penelitian IPB.

Dinas Perikanan dan Kelautan Pemerintah Provinsi Bali. Data Nelayan Provinsi Bali Tahun 2016.

Dinas Kelautan, Perikanan dan Kehutanan Kabupaten Jembrana. Data Nelayan Kabupaten Jembrana Tahun 2016.

Fauzi, A. 2010. Ekonomi Perikanan. Jakarta: Gramedia Pustaka Utama.

Fukuyama, F. 2000. Social Capital, Civil Society, and Development. Third Word Quarterly, 22 (1):7- 200.

Gunawan, Sumodiningrat, Dr., M.Ec. 1997. Ekonometrika Pengantar. Edisi pertama cetakan kelima. Yogyakarta: BPLE.

Gunarsa Putra, I Made. 2016. Analisis
Pengaruh Faktor produksi, Sosial Demografi, dan Modal Sosial Terhadap Produktivitas dan Kesejahteraan Nelayan di Kabupaten Tabanan (Tesis). Denpasar: Fakultas Ekonomi dan Bisnis Universitas Udayana.

Hermanto, F. 1993. Ilmu Usaha Tani. Jakarta: PS Penebar Swadaya.

Imron, Msyuri. 2003. Kemiskinan dalam Masyarakat Nelayan. Jurnal Masyarakat Budaya. PMB-LIPI

Kusnadi. 2009. Keberdayaan Nelayan dan Dinamika Ekonomi Pesisir. Jogjakarta: Lembaga Penelitian Universitas Jember dan Ar-Ruzz Media.

Lenggono, P. Setia. 2004. Modal Sosial Dalam Pengelolaan Tambak (Studi Kasus Pada Komunitas Petambak di Desa Muara Pantuan Kecamatan Anggana Kabupaten Kutai Kertanegara (Tesis). Kertanegara: Universitas Kutai.

Lumban, Judirman Goal. 2015. Analisis Faktor-Faktor Yang Mempengaruhi Pendapatan Nelayan Jermal dan Kapal Motor 5 GT di Kecamatan Simeulue Timur Kabupaten Simeulue Provinsi Aceh (Tesis). Jakarta: Universitas Terbuka.

Lujianti, Ira. 2016. Analisis Tingkat Kesejateraan Nelayan di Kampung Nelayan Seberang Kecamatan Medan Belawan (Skripsi). Medan: Universitas Sumut.

Masyhuri. 1999. Usaha Penangkapan Ikan di Jawa dan Madura: Produktivitas dan Pendapatan Buruh Nelayan. Masyarakat Indonesia, XXIV No. 1.

Mubyarto. 1985. Kegiatan Usaha nelayan dan Kesejahteraan Masyarakat Pesisir. Jakarta: PT Balai Pustaka. 


\section{----------. 2002. Pengantar Ekonomi Pertanian Edisi ketiga. Jakarta: PT Balai Pu-staka.}

Miarso. 2007. Menyemai benih teknologi pendidikan. Jakarta: Pustekom Dinas.

Muhammad, Rafiy, at.all. 2014. Study of Improvement Fishermen Welfare Through Improved Productivity And Model Development In The Coastal North Konawe. The International Journal Of Engineering And Science (IJES), Volume 4 no. 12. Southeast Sulawesi: Departement of economic, Halu Oleo University, Kendari.

Naisbitt. 2002. High tech high touch. Bandung: Mizan.

Nikijuluw, V.P.H. 2003. Aspek Sosial Ekonomi Masyarakat Pesisir dan Strategi Pemberdayaan Mereka dalam Konteks Pengelolaan Sumberdaya Pesisir Secara Terpadu. In : Koleksi Dokumen Proyek Pesisir 1997-2003

Putnam, R.D. 2000. The Prosperous Community: Social Capital and Public Life. American Prospect, 13, Spring, 35-42. In Elinor.

Purbayanto et al. 2004. Kajian Teknis Kemungkinan Pengalihan Pengaturan Perijinan dari GT menjadi Volume Palka pada Kapal Ikan. Makalah tentang "Paradigma baru pengelolaan perikanan yang bertanggungjawab dalam rangka mewujudkan kelestarian sumberdaya dan manfaat ekonomi maksimal" 10-11 Mei 2004.

Riefsa. 2014. Potensi Kelautan Indonesia Bagi Kesejahteraan. Surakarta: CV. Aryheaeko Sinergi Persada.

Rosni. 2012. Analisis Tingkat Kesejahteraan Masyarakat Nelayan di Desa Dahari Selebar Kecamatan Talawi Kabupaten
Batubara (Jurnal). Medan: Universitas Negeri Medan

Sastrawidjaya. 2002. Nelayan Nusantara. Jakarta: Pusat Pengolahan produk Sosial Ekonomi Kelautan dan Perikanan.

Sajogyo. 1996. Pengembangan Daerah dan Pemberdayaan Masyarakat. Jakarta: Bina Rena Pariwara.

Sakata, S. 2004. What is Social Capital? In: Social Capital and International Cooperation. Tokyo: Apan International Cooperation Agency in Japanese.

Setianto, Indradi. 2007. Kapal Perikanan. Semarang: UNDIP.

Sinaga, 2014. Faktor-Faktor yang Mempengaruhi Produksi Bawang Merah: Studi Kasus pada Usahatani di Desa Srigading, Kecamatan Sanden, Kabupaten Bantul, DIY. Yogyakarta: Universitas Atma Jaya.

Soekartawi. 2002. Analisis Usahatani. Jakarta: Universitas Indonesia.

2003. Prinsip Ekonomi Pertanian. Jakarta: Rajawali Press.

2003. Teori Ekonomi Produksi Analisis Fungsi Cobb-Douglas. Rajawali. Jakarta.

Sukirno, Sadono. 2014. Mikroekonomi Teori Pengantar Edisi ketiga. Depok: Rajagrafindo.

Suyana, Utama, Made. 2015. Aplikasi Analisis Kuantitatif. Denpasar: Fakultas Ekonomi Udayana Denpasar.

Todaro, Michael P dan Smith. 2004. Pembangunan Ekonomi Di Dunia Ketiga, Edisi Kedelapan. Jakarta: Erlangga. 
Undang-Undang No. 11 tahun 2009 tentang Kesejahteraan Sosial. Jakarta.

Wahyono, A., Imron, M., dan Nadzir, I. 2014. "Kapasitas adaptif masyarakat pesisir menghadapi perubahan iklim" Kasus pulau gangga. Minahasa Utara: Peneliti Puslit kemasyarakatan dan kebudayaan-LIPI. 